\title{
Referees for 2016
}

(c) Springer Science+Business Media Dordrecht 2016

The Journal of Ethics thanks both the members of its distinguished editorial board and the following philosophers for their excellent assistance to the journal by way of their service as referees:

Raymond Anthony

Jovan Babic

Randolph Clarke

Ann Cudd

Michael Davis

A. Jokic

John Kultgen

Hallvard Lillehammer

Dana Nelkin

George Rainbolt

Jesper Ryberg

David Shoemaker

Michael J. Zimmerman 